\title{
I Konferencja Interdyscyplinarnego Centrum Badań Płci Kulturowej i Tożsamości UAM, Poznań (17 czerwca 2010)
}

W czerwcu 2010 r. rozpoczęło swoją działalność Centrum Badań Płci Kulturowej i Tożsamości Uniwersytetu im. A. Mickiewicza w Poznaniu. W ten sposób liczba polskich uczelni, z kierunkiem studiów i badań genderowych powiększyła się o kolejny przyczółek. Powstanie Centrum było w głównej mierze dziełem prof. dr hab. Ewy Kraskowskiej i dr Agnieszki Gajewskiej, które pracują w Pracowni Krytyki Feministycznej na Wydziale Filologii Polskiej i Klasycznej Uniwersytetu im. A. Mickiewicza w Poznaniu. W funkcjonowanie tej jednostki włączyli się aktywnie również pracownicy Zakładu Historii Wychowania UAM.

Z tej okazji zorganizowano w Collegium Maius UAM konferencję, która miała za zadanie także wskazać potencjalne kierunki zainteresowań twórców Centrum. Spotkanie miało bardzo kameralny charakter, obrady trwały jeden dzień. Zaplanowanych było dziewięć referatów i wystąpień.

Pierwszy głos zabrał Łukasz Kielban. Tematem jego wystąpienia był honor oficera polskiego w dwudziestoleciu międzywojennym. Problematyka tego referatu ukazała złożoność zagadnień genderowych, przez większość postrzeganych tylko i wyłącznie jako kobiece i feministyczne. Bezpośrednio do tych wątków nawiązała już Ewa Kraskowska, która przybliżyła uczestnikom konferencji zagadnienie „małej drugiej fali” feminizmu w PRL-u. Referentka przypomniała twórczość literacką m.in. Anny Świerczyńskiej, Anny Kowalskiej, Marii Dąbrowskiej, Mai Berezowskiej, Stefanii Grodzieńskiej. Stwierdziła także, że początki opozycji antykomunistycznej w Polsce dały też zaczątek tworzenia się w Polsce dyskursów emancypacyjnych. Autorką kolejnego wystąpienia była Elżbieta Adamiak, prekursorka i autorka wielu prac z zakresu teologii feministycznej. Ta tematyka także zdominowała treść referatu, w którym poruszone zostały m.in. takie problemy, jak: rola kobiet w Kościele, beatyfikacje kobiet, kwestie mariologiczne. Następny referat wygłosiła Iwona Chmura-Rutkowska, która skoncentrowała się wokół przemocy rówieśniczej i dyskryminacji ze względu na płeć w codziennych doświadczeniach polskich gimnazjalistów. Autorka tego wystąpienia wykazała, że zjawisko przez nią badane nie ma charakteru incydentalnego i jest immanentną cechą polskiego systemu oświaty. Monika Frąckowiak-Sochańska natomiast połączyła zdrowie psychiczne z płcią społeczno-kulturową. Jednym z podjętych przez referentkę wątków było zjawisko depresji, najbardziej rozpowszechnione współcześnie zaburzenie psychiczne i jednocześnie najbardziej zróżnicowane płciowo. Następnie głos zabrała Edyta Głowacka-Sobiech, która historycznie potraktowała zjawisko aborcji, jakie pozostaje stałą częścią dziejów człowieka. Autorka wystąpienia stwierdziła, że przerywań ciąży dokonywano w każdej epoce historycznej, różnie jednak było to oceniane. Jedno natomiast zawsze było stałe: wina kobiet zarówno niedoszłych matek, jak i znachorek, babek i domorosłych lekarek, które dokonywały aborcji. W zupełnie inną rzeczywistość wprowadziła uczestników konferencji kolejna prelegentka - Grażyna Gajewska. Jej wystąpienie nosiło tytuł: „Erotyka manekinów”, a dotyczyło sposobów, w jaki przedstawiana była dawniej w literaturze, a współcześnie w kulturze 
masowej kobiecość. Równie egzotyczny temat, dosłownie i w przenośni, zaprezentowała Marta Mazurek. Mówiła ona bowiem o womanismie, czyli o czarnym feminizmie. Swoje rozważania autorka wystąpienia oparła na coraz licznie powstającej literaturze feministycznej (Alice Walker) oraz na wyjaśnieniu samego pojęcia „womanism”, które w języku polskim brzmieć może „kobietyzm” (i konsekwentnie kobieta zajmująca się tymi problemami to „woman - ist”, czyli „kobietystka”). Ostatni referat zaprezentowały Maria Natalia Kistowska i Agnieszka Hrynyk. Nosił on tytuł: „O tym , co niezwykle psuje image”, czyli kto i dlaczego nie lubi feminizmu w Rosji”, a dotyczył problemów współczesnych Rosjanek, szczególnie tych, które z feminizmem się utożsamiają.

Konferencja miała bardzo żywy przebieg. Po zaprezentowaniu referatów toczyły się interesujące dyskusje i wiele wątków, zasygnalizowanych jedynie w wystąpieniach, zostało twórczo rozwiniętych. Konferencja zakończyła się także propozycją otwarcia przez Centrum studiów podyplomowych i kwestie związane z ich organizacją były finałem spotkania.

Edyta Głowacka-Sobiech

\section{Konferencja popularnonaukowa „Aktualność pedagogiki Marii Grzegorzewskiej w kontekście współczesnych wyzwań edukacyjnych" (Żary, 17 czerwca 2010)}

Zespół Szkół Specjalnych im. Marii Grzegorzewskiej w Żarach obchodził w roku 2010 dwie ważne rocznice: jubileusz 55-lecia utworzenia Szkoły i 5-lecia nadania jej imienia Marii Grzegorzewskiej. Pracownicy Placówki uznali, że najlepszą formą uczczenia tych rocznic będzie organizacja konferencji popularnonaukowej, skierowanej do społeczności lokalnej, władz samorządowych, urzędników kuratorium oświaty, pracowników żarskich szkół i przedszkoli (szczególnie tych, które prowadzą oddziały integracyjne) oraz rodziców dzieci niepełnosprawnych. Prezentacja dorobku wielkiej Patronki stała się okazją do przybliżenia wszystkim wymienionym osobom specyfiki wychowania i nauczania specjalnego oraz zaprezentowania tak tradycyjnych i sprawdzonych metod pracy stosowanych w Placówce, jak też metod nowatorskich, których skuteczność gwarantuje zakorzenienie w bogatej tradycji, reprezentowanej przez dzieło Marii Grzegorzewskiej.

Przedsięwzięcie zrealizowane zostało we współpracy z Łużycką Wyższą Szkołą Humanistyczną im. Benedykta Solfy w Żarach. Uczelnia udostępniła swe pomieszczenia dla przeprowadzenia konferencji, zaś jej pracownicy weszli w skład Rady Naukowo-Programowej.

Konferencja „Aktualność pedagogiki Marii Grzegorzewskiej w kontekście współczesnych wyzwań edukacyjnych” odbyła się 17 czerwca 2010 r. w siedzibie ŁWSH. W skład 